\title{
A Record of Communal Nesting in the Barn Owl (Tyto alba)
}

Author(s): Ezra Hadad, Alexandre Roulin, and Motti Charter

Source: The Wilson Journal of Ornithology, 127(1):114-119.

Published By: The Wilson Ornithological Society

DOI: http://dx.doi.org/10.1676/13-180.1

URL: http://www.bioone.org/doi/full/10.1676/13-180.1

BioOne (www.bioone.org) is a nonprofit, online aggregation of core research in the biological, ecological, and environmental sciences. BioOne provides a sustainable online platform for over 170 journals and books published by nonprofit societies, associations, museums, institutions, and presses.

Your use of this PDF, the BioOne Web site, and all posted and associated content indicates your acceptance of BioOne's Terms of Use, available at www.bioone.org/page/terms of use.

Usage of BioOne content is strictly limited to personal, educational, and non-commercial use.

Commercial inquiries or rights and permissions requests should be directed to the individual publisher as copyright holder. 


\title{
A Record of Communal Nesting in the Barn Owl (Tyto alba)
}

\author{
Ezra Hadad, ${ }^{1}$ Alexandre Roulin, ${ }^{2}$ and Motti Charter ${ }^{3,4}$
}

\begin{abstract}
We report a unique case of two female Barn Owls laying eggs and incubating together in a single nest cup in a communal nest. A trio of two females and one male bred in an abandoned water tower in 2013 in Israel. Both females incubated/brooded together in the communal nest, and all three individuals brought food to the communal family. The two females laid 20 eggs, of which 19 hatched and 16 fledged. Received 26 October 2013. Accepted 22 July 2014.
\end{abstract}

Key words: Barn Owl, communal nesting, cooperative breeding, Israel, polygamy, Tyto alba.

\footnotetext{
${ }^{1}$ Israel Nature and Parks Authority, 3 Am Ve'Olamo Street, Jerusalem, 95463.

${ }^{2}$ Department of Ecology and Evolution, Building Biophore, University of Lausanne, 1015 Lausanne, Switzerland.

${ }^{3}$ Department of Evolutionary and Environmental Biology, University of Haifa, Haifa 31905, Israel.

${ }^{4}$ Corresponding author; e-mail: chartermotti@gmail.com
}

While monogamy is the most common mating system in birds (Lack 1968), a number of other systems have been observed. These include, polygamy, in which one male secures several females; and polyandry, in which one female breeds with several males that take care of her clutches laid in succession. Additional breeding systems include brood parasitism (laying eggs in the nest of other species or conspecifics), cooperative breeding (non-breeding birds help others rear their brood), and communal breeding. The latter system is found in small mammals such as mice, in which several females (often sisters) give birth in the same nest and raise their young together without discrimination (e.g., König 1989, Manning et al. 1995). In birds, however, communal nesting is much rarer (for examples see Rowley 1978, Vehrencamp 1986, Lauro et al. 1992, Jamieson et al. 1994, Kimball et al. 2003). 


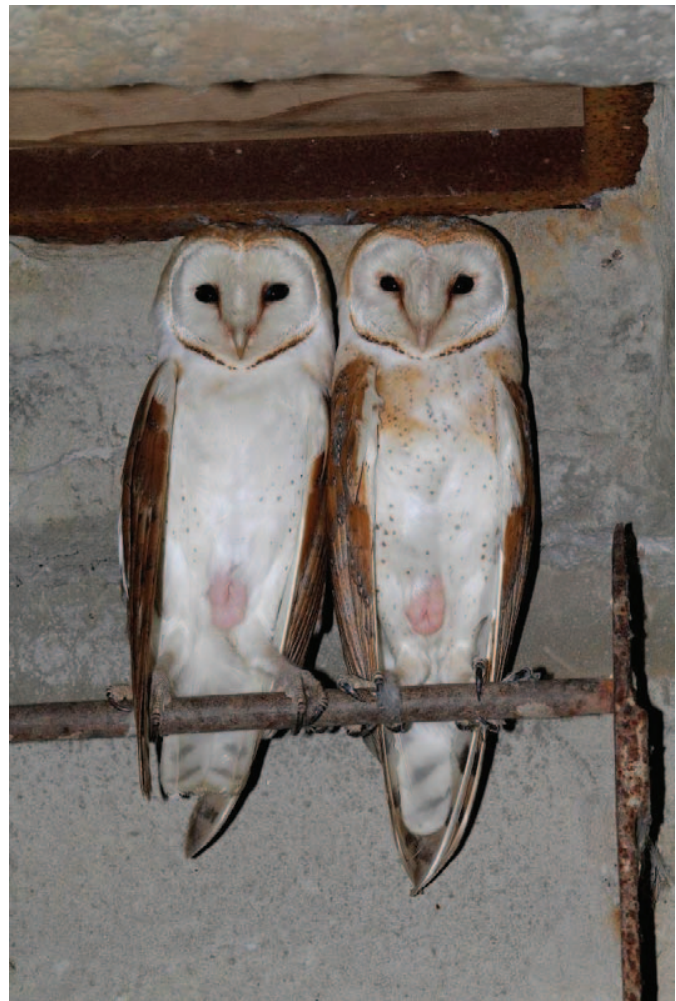

FIG. 1. The two female Barn Owls perched next to each other. The brood patch in both females is clearly visible (Photo: Ezra Hadad).

It is necessary to differentiate in this respect between nests that have non-breeding bird helpers (cooperative breeding) and those that are composed of laying females only (communal nesting). We define "nesting communally" as when females lay eggs with conspecifics in the same nest and/or when the offspring of all breeding females are raised together.

Most owls are monogamous with polygamy being the exception (see review in Korpimäki 1988), and extra-pair paternity is rare (Roulin et al. 2004). Polyandry occurs when two males assist to raise the same young (Faaborg et al. 1995) as found in Long-eared Owls (Asio otus; Marks et al. 2002) and in Boreal Owls (Aegolius funereus, Korpimäki et al. 2011).

In Barn Owls (Tyto alba), polyandry has been reported, in which females abandon their first annual brood when their offspring are already able to consume prey by themselves to start a second breeding attempt with another male while their first male completes parental duties at the first nest (e.g., Schubert 1959, Altmüller 1976, Roulin
2002, Kniprath and Stier-Kniprath 2011, Henry et al. 2013). Desertion is adaptive as the female can then start a second breeding attempt with a new male in another nest site while her first mate continues to complete parental care duties at the first nest (Roulin 2002, Henry et al. 2013).

Polygamy has also been recorded, with males breeding concomitantly with two females at two different nest sites (Bunn et al. 1982, Baudvin 1986, Marti 1990, Epple 1993, De Bruijn 1994, Boenigk 2000). In some cases, breeding Barn Owls have been found to be tolerant of other bird species breeding in very close proximity (Schönfled and Girbig 1975, Bunn et al. 1982, Hasenclever and Tiemeyer 1991, Brandt and Seebass 1994), as well as of conspecifics breeding as close as $1 \mathrm{~m}$ (Baudvin 1975, Epple 1993, Boenigk 2000, Marti 1990). One instance of semicolonial breeding by Barn Owls was also reported (Smith et al. 1974) and also observed in other species (Common Kestrel Falco tinnunculus, Rock Pigeon Columba livia, Western Jackdaw Coloeus monedula). Communal breeding in Barn Owls has been reported twice (Marti 1990, Taylor 2004), and in both cases females laid two separate clutches in the same cavities and, after the young hatched, raised them together.

In Israel, Barn Owls breed in both nest boxes (Meyrom et al. 2009, Charter et al. 2010, Charter et al. 2012) and in man-made structures (Meyrom et al. 2008) with breeding densities as high as 233 breeding pairs per $100 \mathrm{~km}^{2}$ (Meyrom et al. 2009). Breeding pairs can breed in close proximity to one another as two pairs were reported breeding in nest boxes only $5 \mathrm{~m}$ apart in the Jezreel Valley, Israel (K. Meyrom, pers. comm.).

Here we present a case of communal nesting by Barn Owls when two females laid eggs in the same nest cup and incubated them together.

\section{METHODS}

During March-June 2013, a Barn Owl bred inside an old abandoned round water tower $(4.0 \mathrm{~m}$ in diameter) in the Judea region of south Israel $\left(31^{\circ} 37^{\prime} 37.91^{\prime \prime} \mathrm{N}, 34^{\circ} 47^{\prime} 38.76^{\prime \prime} \mathrm{E}\right)$ and the nest was monitored ( $n=11$ visits). A ScoutGuard SG565 trail camera with a movement sensor that took both videos and still photos was added in the tower on 26 March.

\section{RESULTS}

On 9 March 2013, two adult females with brood patches (Fig. 1) were observed together incubating 


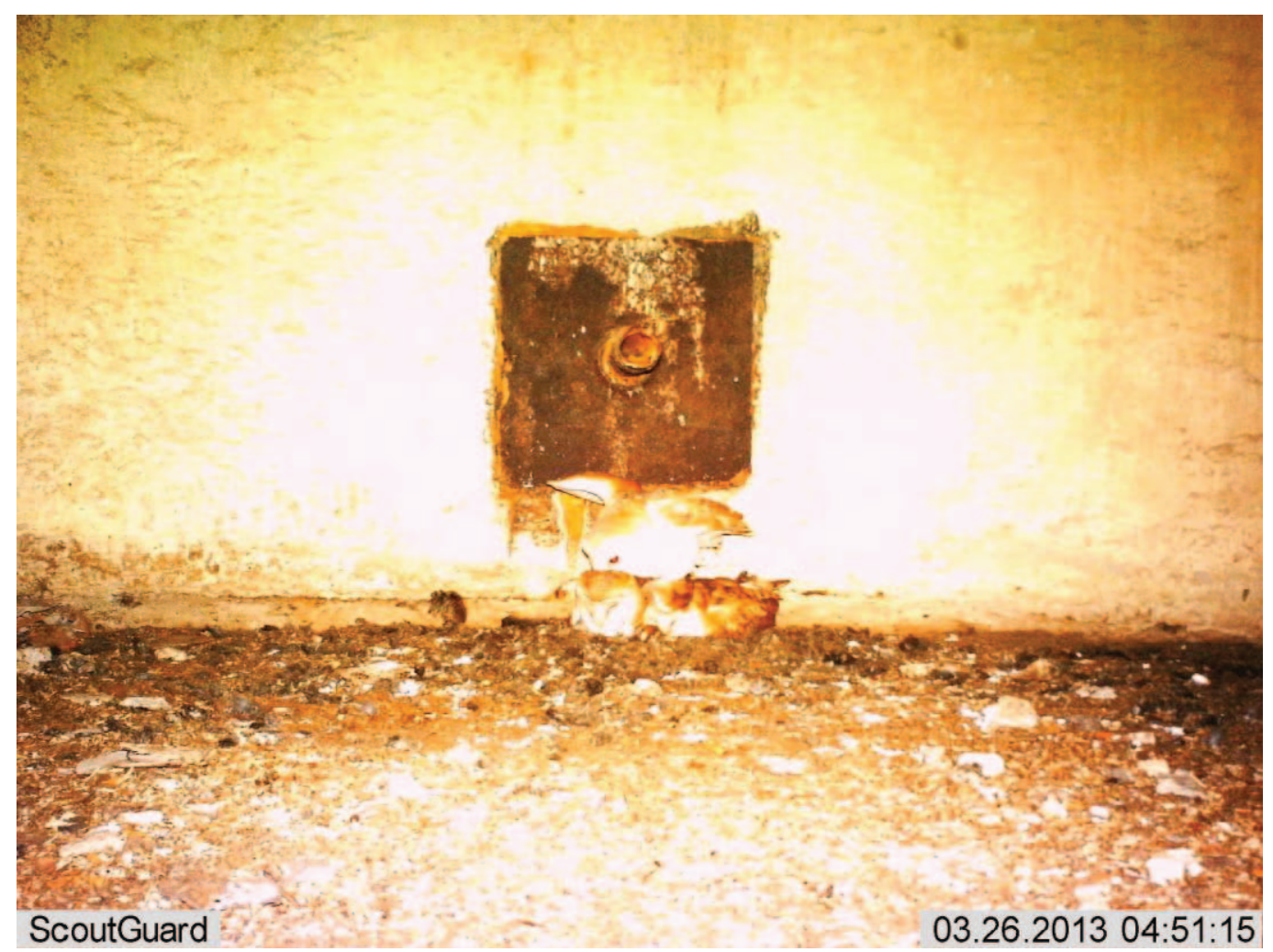

FIG. 2. The two female Barn Owls incubating 20 eggs together while the male mates with one of the two females (Photo: Ezra Hadad).

9 eggs in a shallow scrape on the ground, while a male stood guard a few meters away. The lone male mated with both females, which jointly incubated/ brooded the eggs and nestlings (Figs. 2, 3).

The two females laid 20 eggs, 19 of which hatched and the trio fledged 16 young (Table 1). Both females were observed incubating and also brooding together on 4 April. On 9 April, 10-12 April, and 16 April, only the lighter colored female incubated while the darker female stood guard close by. On 14 April, neither of the females were seen incubating, but both they and the male brought prey to the nest.

\section{DISCUSSION}

Although Barn Owl females have been observed incubating clutches within the same cavity as close as a few centimeters apart (Marti 1990, Taylor 2004), we report the first case of females laying and incubating eggs together in the same nest scrape. Taylor (2004) and Marti (1990) both reported instance in which two females each laid separate clutches only a few centimeters apart from one another, but not together as reported here. After the young hatched, both females in this study continued to feed the young together, as also found in the cases in which the females

TABLE 1. Timeline of the number of eggs and nestlings found in the communal nest of Barn Owls.

\begin{tabular}{lccccccccccc}
\hline & 9 March & 11 March & 21 March & 24 March & 26 March & 8 April & 16 April & 25 April & 26 April & 29 April & 17 May \\
\hline Clutch Size & 9 & 11 & 17 & 19 & 20 & 13 & 7 & $1^{\text {a }}$ & & & \\
Brood Size & & & & & & 7 & 13 & 19 & 18 & 17 & 16 \\
\hline
\end{tabular}

\footnotetext{
${ }^{\text {a }}$ Never hatched.
} 


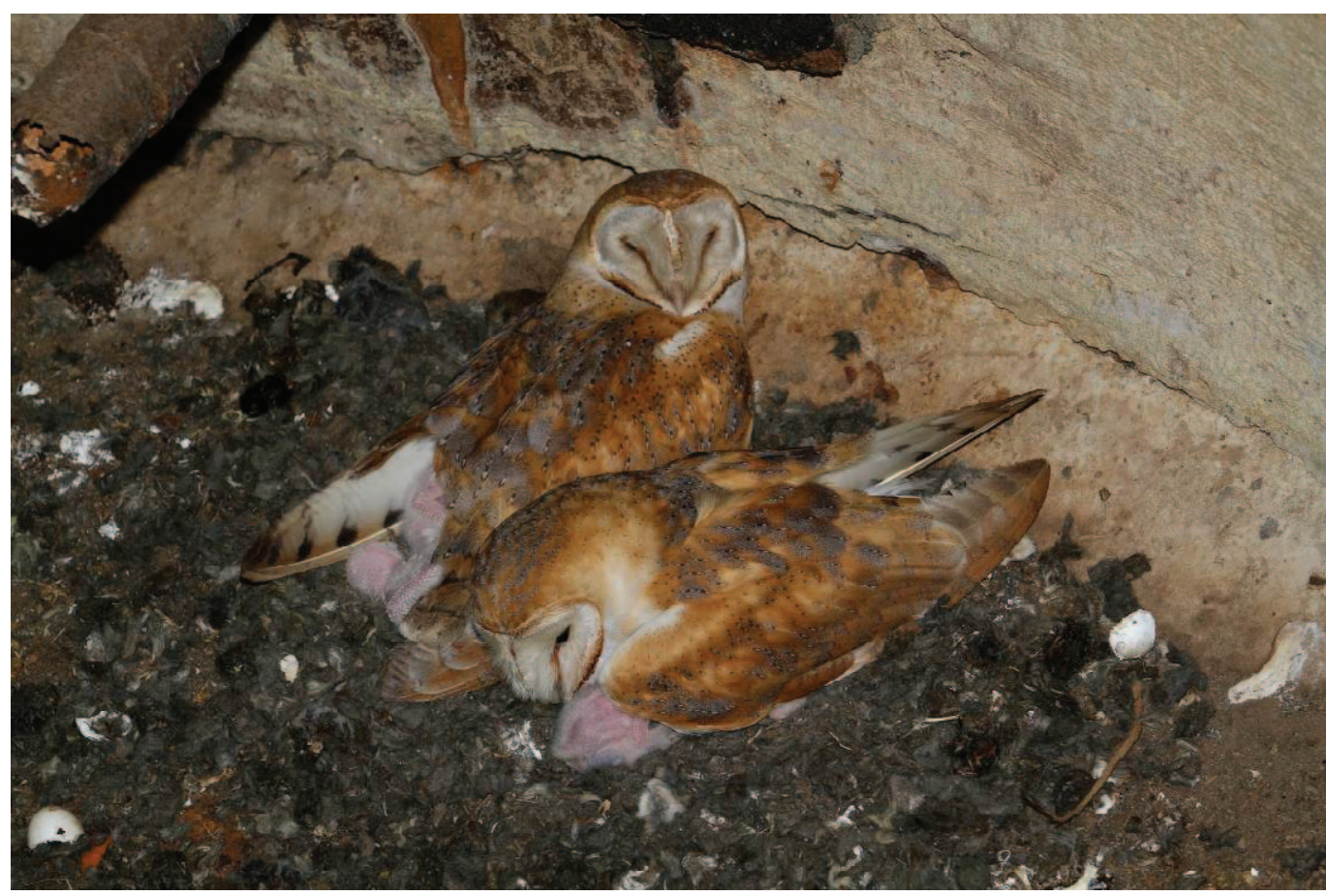

FIG. 3. The two female Barn Owls incubating/brooding together seven nestlings and 13 eggs (Photo: Ezra Hadad).

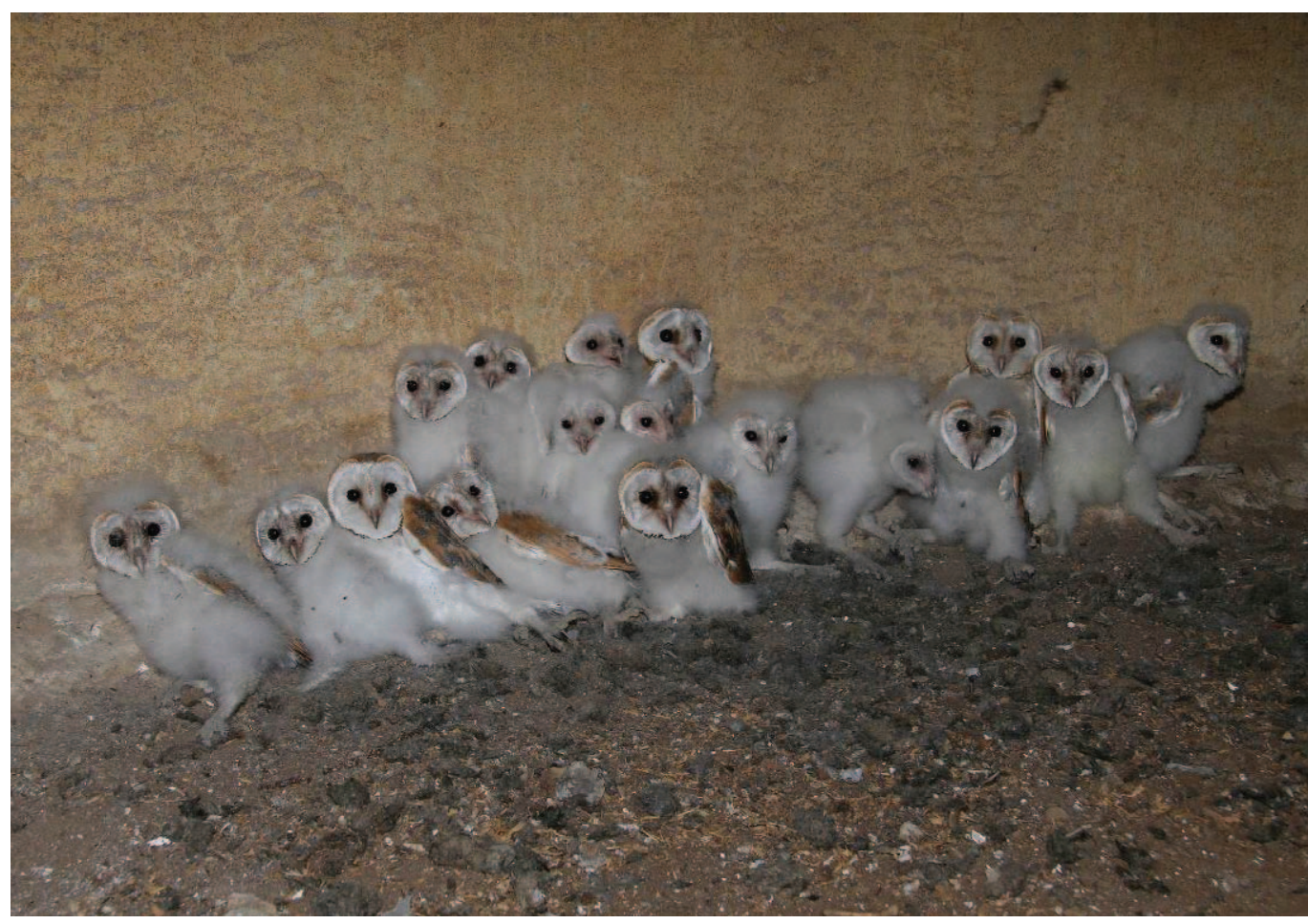

FIG. 4. Seventeen of the 19 nestlings of the communal nest of Barn Owls (Photo: Ezra Hadad). 
incubated the clutches separately (Marti 1990, Taylor 2004).

We are unsure whether the two communally nesting females were related, but it is documented that related Barn Owls have bred together monogamously (one male and one female) in Europe (Shaw 1989, Roulin 1996), and we have also recorded siblings (three cases) breeding together in Israel (MC, unpubl. data).

Even though we do not know the exact number of eggs laid by each female, we feel confident that both females laid eggs, as both females had a brood patch, and within this population in Israel we have never observed a female laying more than 14 eggs $($ mean $=7.8, \mathrm{SE}=0.11, \max =14)$. The average number of young fledged from this study area during the 2008-2013 breeding seasons per laying pair is only 3.6 nestlings ( $\mathrm{SE}=0.3, n$ $=5$, $\max =11)(\mathrm{MC}$, unpubl. data), which is far fewer than the 16 young fledged by the trio in this study. The ability of the trio to raise all 16 young is quite a feat and points to the male's ability to provide food initially when the females were incubating and not hunting. Unlike Marti (1990) and Taylor's (2004) observations of females in communal nests having lower reproductive success than monogamous females, in our case, the number of young fledged was much higher than the average for monogamous females.

Since Barn Owls can be semi-colonial, and breed quite close to each other and to other bird species, it is not surprising that they could also be communal breeders. Even though we are aware that this report is anecdotal, it shows the potential of this species to develop cooperative behavior (Roulin et al. 2012).

\section{ACKNOWLEDGMENTS}

We give special thanks to Irit Shachar from Kibbutz Gat for letting us know about the location of the nest and Naomi Paz for editorial assistance. We are grateful to two anonymous reviewers who helped us improve the manuscript. The study was financed by the Addax-Oryx foundation.

\section{LITERATURE CITED}

AltMÜLlER, R. 1976. Schachtelbrut eines SchleiereulenWeibchens (Tyto alba). Vogelk. Ber. Niedersachs 8:9-10.

Baudvin, H. 1975. Breeding of the Barn Owl Tyto alba in the Cote d'Or (east of France): first results. Le Jean le Blanc 14:1-52.

BAUdvin, H. 1986. La reproduction de la chouette effraie (Tyto alba). Le Jean-le-Blanc 25:1-125.
BoEnIGK, G. 2000. Ungewöhnliche 'Polygynie' bei der Schleiereule (Tyto alba). Vogelk. Ber. Nieders 32:5356.

Brandt, T. And C. Seebass. 1994. Die Schleiereule. AULA-Verlag, Wiesbaden.

Bunn, D. S., A. B. Warburton, And Wilson. 1982. The Barn Owl. T and A. D. Poyser, Waterhouses, UK.

Charter, M., K. Meyrom, Y. Leshem, S. Aviel, I. IZhaki, AND Y. Motro. 2010. Does nest box location and orientation affect occupation rate and breeding success of Barn Owls Tyto alba in a semi-arid environment? Acta Ornithologica 44:115-119.

Charter, M., Y. Leshem, K. Meyrom, O. Peleg, and A. Roulin. 2012. The importance of micro-habitat in the breeding of Barn Owls Tyto alba. Bird Study 59:368371.

DE BRUiJn, O. 1994. Population ecology and conservation of the Barn Owl Tyto alba in farmland habitats in Liemers and Achterhoek (The Netherlands) Ardea 82:1-109.

Epple, W. 1993. Schleiereulen. Karlsruhe, Germany: G. Braun GmbH. 107.

Faaborg, J., P. G. Parker, L. Delay, T. De Vries, J. C. Bednarz, S. Maria Paz, J. Naranjo, and T. Waite. 1995. Confirmation of cooperative polyandry in the Galápagos Hawk (Buteo galapagoensis). Behavioral Ecology and Sociobiology 36:83-90.

Hasenclever, H. AND V. Tiemeyer. 1991. Brutgemeinschaft des Turmfalken (Falco tinnunculus) und der Schleiereule (Tyto alba) in einem Brutkasten. Charadrius 27:14-18.

Henry, I., S. Antoniazza, S. Dubey, C. Simon, C. Waldvogel, R. Burri, And A. Roulin. 2013. Multiple paternity in polyandrous Barn Owls (Tyto alba). PLoS ONE 8(11):e80112.

Jamieson, I. G., J. S. Quinn, P. A. Rose, AND B. N. White. 1994. Shared paternity among non-relatives is a result of an egalitarian mating system in a communally breeding bird, the Pukeko. Proceedings of the Royal Society of London, Series B. 257:271-277.

Kimball, R. T., P. G. Parker, and J. C. Bednarz. 2003. Occurrence and evolution of cooperative breeding among the diurnal raptors (Accipitridae and Falconidae). Auk 120:717-729.

KNIPRATH, E. AND S. STIER-KNIPRATH. 2011. Umstände des Partnerwechsels für eine Zweitbrut der Schleiereule Tyto alba. Vogelwarte 49:75-77.

KöNIG, B. 1989. Kin recognition and maternal care under restricted feeding in house mice (Mus musculus). Ethology 82:328-343.

KORPIMÄKI, E. 1988. Factors promoting polygyny in European birds of prey- a hypothesis. Oecologia 77: 278-285.

KorpimäKi, E., P. SAlo, And J. VAlKama. 2011. Sequential polyandry by brood desertion increases female fitness in a bird with obligatory bi-parental care. Behavioral Ecology and Sociobiology 65:10931102.

LACK, D. 1968. Ecological adaptations for breeding in birds. Methuen, London, UK. 
LAURO, B., E. NOL, AND M. ViCARI. 1992. Nesting density and communal breeding in American Oystercatchers. Condor 94:286-289.

Manning, C. J., D. A. Dewsbury, E. K. Wakeland, And W. K. PotTs. 1995. Communal nesting and communal nursing in house mice, Mus musculus domesticus. Animal Behaviour 50:741-751.

MARKS, J. S., J. L. Dickinson, AND J. HAYdock. 2002. Serial polyandry and alloparenting in Long-eared Owls. Condor 104:202-204.

MARTI, C. D. 1990. Same-nest polygyny in the Barn Owl. Condor 92:261.

Meyrom, K., Y. Leshem, And M. Charter. 2008. Barn Owl Tyto alba breeding success in man- made structures in the Jordan Rift valley, Israel. Sandgrouse 30:134-137.

Meyrom, K., Y. Motro, Y. Leshem, S. Aviel, I. Izhaki, F. ArgYle, AND M. Charter. 2009. Nest-box use by the Barn Owl Tyto alba in a biological pest control program in the Beit She'an valley, Israel. Ardea 97:463-467.

Roulin, A. 1996. Inceste chez la chouette effraie Tyto alba. Alauda 64:458-459.

Roulin, A. 2002. Offspring desertion by double-brooded female Barn Owls (Tyto alba). Auk 119:515-519.

Roulin, A., A. DA Silva, AND C. A. Ruppli. 2012. Dominant nestlings displaying female-like melanin coloration behave altruistically in the Barn Owl. Animal Behaviour 84:1229-1236.

Roulin, A., W. Müller, L. Sasvari, C. Dijkstra, A. L. Ducrest, C. Riols, AND M. WinK. 2004. Extra-pair paternity, testes size and testosterone level in relation to colour polymorphism in the Barn Owl Tyto alba. Journal of Avian Biology 35:492-500.

Rowley, I. 1978. Communal activities among Whitewinged Choughs Corcorax melanorhamphus. Ibis 120:178-197.

SChÖNFELD, M. AND G. GIRBIG. 1975. Beitrage zur Brutbiologie der Schleiereule, Tyto alba, unter besonderer Berucksichtigung der Abhangigkeit von der Feldmausdichte. Hercynia NF 12:257-319.

SCHUBERT, P. 1959. Ineinandergeschachtelte Bruten der Schleiereule. Falke 6:33-34.

Shaw, G. AND A. Dowell. 1989. Breeding by closely related Barn Owls. Ringing and Migration 10:98.

Smith, D. G., C. R. Wilson, And H. H. Frost. 1974. History and ecology of a colony of Barn Owls in Utah. Condor 76:131-136.

TAYLOR, I. R. 2004. Barn Owls: predator-prey relationships and conservation. Cambridge, Cambridge University Press, New York, USA.

VeHRENCAMP, S. L. 1986. Breeding roles and pairing patterns within communal groups of Groove-billed Anis. Animal Behaviour 34:347-366. 